\title{
COVID-19 molecular level laboratory diagnoses
}

\author{
Pohanka M \\ Faculty of Military Health Sciences, University of Defense, Hradec Kralove, Czech Republic. \\ miroslav.pohanka@gmail.com
}

\begin{abstract}
AIMS: Aims: The Coronavirus Disease 2019 (COVID-19) caused not only global pandemic, but it also pointed at unprepared health care systems and countermeasures were introduced under the pressure of urgent circumstances. This review is focused on discussion and critical evaluation of instrumental tools for COVID-19 diagnosis that were developed in the last months.

METHODS: Survey of actual literature and scientific reports was made. The most substantial analytical and diagnostical methods were identified and described. Principles and limitations of the methods are described, and actual papers are cited in this review.

RESULTS: Analytical and diagnostical methods like Polymerase Chain Reaction (PCR), Loop-mediated isothermal Amplification (LAMP), Lateral Flow Immunochromatography Assay (LFIA), Enzyme-Linked Immunosorbent Assay (ELISA), biosensors and ChemiLuminescence ImmunoAssay (CLIA) are discussed for assay of viral particles, antigens and specific host antibodies in blood, serum, plasma, nasopharyngeal swab and other samples in order to diagnose COVID-19.

CONCLUSIONS: The Coronavirus Disease 2019 (COVID-19) is an emerging disease that has spread over the world since the end of year 2019. The global epidemic pointed at the necessity to introduce sensitive methods for instrumental diagnosis of COVID-19 and distinguishing it from the other viral diseases. (Tab. 2, Ref. 96). Text in PDF www.elis.sk

KEY WORDS: antibody, biosensor, COVID-19, Coronavirus Disease 2019, diagnosis, enzyme-linked immunosorbent assay, ELISA, immunoassay, polymerase chain reaction, severe acute respiratory syndrome coronavirus 2, SARS-CoV-2.
\end{abstract}

\section{Introduction}

The Coronavirus Disease 2019 (COVID-19) is an infection caused by a zoonotic coronavirus taxonomically entitled as Severe Acute Respiratory Syndrome Coronavirus 2 (SARS-CoV-2). The original local epidemy in China first observed in Wuhan city turned into a global pandemic starting in the 2019 and extensively growing over the world in the year 2020 (1-4). The COVID-19 can be recognized using clinical differential diagnosis; however, there are significant limitations regarding this approach. The fact that many infected patients become vectors for the disease but remain without symptomatic clinical manifestation or with weak symptomatic manifestation without the disease perception is a significant problem. Differential diagnosis becomes inapplicable for these cases (5-9). Another drawbacks of differential diagnosis can be expected for examination of infected children, who

Faculty of Military Health Sciences, University of Defense, Hradec Kralove, Czech Republic

Address for correspondence: M. Pohanka, RND, DSc, PhD, Faculty of Military Health Sciences, University of Defense, Trebesska 1575, CZ-500 01 Hradec Kralove, Czech Republic.

Acknowledgements: This work was supported by A long-term organization development plan "Medical Aspects of Weapons of Mass Destruction" (Faculty of Military Health Sciences, University of Defense, Czech Republic). have either different or no manifestation than the adult patients and overall impact of COVID-19 on children is fortunately very mild (10). The differential diagnosis of COVID-19 can be further improved by instrumental techniques like computed tomography scan (11-14). Though these instruments do not plausibly confirm the particular disease, they make the diagnosis specific and they can also reveal related pathologies.

Unambiguous confirmation of the disease and final diagnosis are a task for specific laboratory methods where genetic information, unique structures or antibodies specific to SARS-CoV-2 are determined. Various methods are currently available and each of them has its pros and cons in the both laboratory reliability and diagnostical interpretability. The situation about used methods and its specific applications is progressively developing as the disease became a serious world matter and considerable effort is given to resolving of the current problems. This review is focused on survey and discussion of laboratory methods used for COVID-19. Because the disease is new, the diagnostic methods are newly researched and developed on the standard genetical, immunochemical etc. platforms. The newly introduced methods are described in this work.

\section{SARS-CoV-2 genetic information revealing}

SARS-CoV-2 is a single-stranded positive-sense RNA virus and a recognition of specific sequences in the RNA is an impor- 
Tab. 1. Basic specifications of COVID-19 and SARS-CoV-2 as outcomes for an instrumental diagnosis.

\begin{tabular}{ll}
\hline Specification & Description \\
\hline type of virus & single-stranded positive-sense RNA \\
\hline $\begin{array}{l}\text { specific parts in genetic } \\
\text { information suitable for diagnosis }\end{array}$ & $\begin{array}{l}\text { ORF 1b gene; N protein gene } \\
\text { including N1 and N2 genes; S } \\
\text { protein gene }\end{array}$ \\
\hline $\begin{array}{l}\text { virion surface proteins } \\
\text { spike (S), and nucleocapsid (N) } \\
\text { proteins }\end{array}$ \\
$\begin{array}{ll}\text { protein for revealing of SARS CoV-2 } \\
\text { by an immunoassay }\end{array}$ & protein S is the most relevant \\
$\begin{array}{l}\text { antibodies produced during } \\
\text { COVID-19 }\end{array}$ & $\begin{array}{l}\text { IgA, IgG, IgM } \\
\text { time lapse of antibodies } \\
\text { production }\end{array}$ \\
$\begin{array}{l}\text { main antigenic structure targeted } \\
\text { by the antibodies in the blood of } \\
\text { patients with COVID-19 }\end{array}$ & $\begin{array}{l}\text { protein S is the most relevant, } \\
\text { most of current test on anti-S1 } \\
\text { antibodies }\end{array}$ \\
\hline
\end{tabular}

tant way in revealing infected patients (15-19). Polymerase Chain Reaction (PCR) and Loop-mediated isothermal Amplification (LAMP) can be mentioned as the two significant methods suitable for identification SARS-CoV-2 based on recognizing its genetical information. Other techniques common in molecular biology are available as well and sequencing of isolates can be also performed for identification purpose and origin of the virus revealing (20). The tests for detecting SARS-CoV-2 genetic information are not typically suitable for point-of-care diagnostic; on the other hand, plausibility of the results is the major advantage. Blood, saliva, oropharyngeal samples and faeces can be mentioned as applicable specimens for the test $(21,22)$. The use of nasopharyngeal swabs is the most common way how to acquire samples for a genetical analysis (23-25). In the study by Lin and co-workers, sputum specimens were more suitable for PCR tests than throat swabs (26). The use of swabs seems to be optimal for sampling in genetical test considering overall effectivity, reduction of time necessary for a patient examination, patients' comfort and safety of medical personnel. Basic specifications of COVID-19 and SARS-CoV-2 as outcomes for diagnosis are summarized in Table 1 .

PCR tests are available and most of clinical laboratories testing samples during the COVID-19 pandemic are equipped with PCR analysers beside the other standard techniques. Many commercial PCR test have been developed and introduced in the market since the start of COVID-19 pandemics (27). Quantitative (also known under synonymic real-time) reverse transcriptase PSR (qRT PCR) is the particular technique for laboratory testing (28-30). Typical qRT PCR is focused on N1 and N2 genes coding viral nucleocapsid, this target is widely recommended by Center for Disease Control and Prevention (Atlanta, USA) $(28,31)$. Other primer sets for PCR are focused on spike and envelope genes and they have valid emergency use authorization (EUA). For instance Altona Real Star (Altona Diagnostic, Hamburg, Germany) qRT PCR focused on envelope and spike genes and SHC EUA test (Sandford Health; Sioux Falls, South Dakota, USA) qRT PCR for envelope gene were compared with the N1, N1 targeting qRT PCR and great agreement between the results was achieved, when clinical samples were measured (32). In another paper, qRT PCR focused on open reading frame (ORF) $1 \mathrm{~b}$ gene was described and compared to the assay focused on the $\mathrm{N}$ genes (33). The ORF $1 \mathrm{~b}$ exerted a lower sensitivity as only $62.5 \%$ of positive patients (total tested 23 ) were recognized while diagnostics by $\mathrm{N}$ gene was fully successful. Nevertheless, the authors concluded their work by the statement that the qRT PCR for ORF $1 b$ gene can be an alternative to the other types of PCR for SARS-CoV-2.

Reverse transcription LAMP (RT LAMP) for SARS-CoV-2 is simpler, cheaper, faster and thus more available for in and out laboratory diagnosis than qRT PCR and a simple coloration as an outputting signal is an advantage for a fast and simple measurement as well (34-43). On the other hand, LAMP has typically a lower sensitivity compared to PCR, this specification is the major drawback of the LAMP assay, when it is considered as an alternative to PCR. The lower sensitivity can result into false negativity, when COVID-19 is diagnosed. In the study by Thi and co-workers, a colorimetric RT LAMP was compared to qRT PCR and the authors stated that the both methods were in a good mutual correlation (44). The RT LAMP had a good specificity (99.5\%) though it had a little lower sensitivity ( $86 \%$ ), when compared to 30 cycles of qRT PCR. On the other hand, the tested RT LAMP was easier for performance and even RNA isolation was not necessary as a direct use of swab as a sample was possible. The RT LAMP appears to be a relevant competitor to qRT PCR and both methods have their advantages and disadvantages. In another experiment, RT LAMP was tested on samples from 223 patients with COVID-19 (confirmed by qRT PCR) and other 143 patients suffering from other respiratory diseases (45). The authors claimed that the limit of detection for the RT LAMP was equal to 42 copies of RNA per a reaction. The colorimetric assay was suitable to be evaluated by a naked eye and the assay had a quite low false negativity comparing to qRT PCR: 212 respective 219 from the total 223 positive samples were recognized by an assay lasting 60 respective 90 minutes. No false positivity occurred, when the samples from 143 patients suffering from other respiratory diseases were tested. The described RT LAMP can be performed on various samples like saliva, throat swab samples, but the best results were obtained using nasopharyngeal swab samples. Samples like blood, serum or plasma from blood can be also used. Considering all aforementioned studies, RT LAMP appears to be a promising method for the surveillance of SARS-CoV-2 presence in humans. Though it is less sensitive than qRT PCR, it can be easily distributed and performed nearly as a point-of-care diagnosis and thus help to manage emergency situations like the COVID-19 pandemic is.

\section{Detection of antigens}

Direct recognition of surface structures of SARS-CoV-2 would be another way to recognize the pathogen although the aforementioned genetic tests would be probably more sensitive and applicable for practical tests in clinical laboratories. Similar samples like in the PCR and LAMP test can be used for the antigen determination. The SARS-CoV-2 virion particles contains three major 
group of proteins containing specific areas but also parts containing homologies with other relative virus families. Membrane (M), envelope $(\mathrm{E})$, spike $(\mathrm{S})$, and nucleocapsid $(\mathrm{N})$ proteins can be mentioned (46-48). S protein appears to be the most convenient for an immunoassay because it is a unique protein responsible for virus interaction with angiotensin-converting enzyme receptor on host cells (49-52). The studies on surface antigenic structures are necessary not only for analytical respective diagnostical purposes, but also for the identification of structures that would serve for development of a vaccine (53-56). The $\mathrm{N}$ and $\mathrm{S}$ proteins (57) and protein glycations (58) can be studied as specific determinants. Similarities between SARS-CoV-2 proteins and proteins from the other viruses should be taken into consideration. For instance, homologies between SARS-CoV-2 S protein and dengue virus were reported (59). These homologies can cause a false positive diagnosis, when an antigen is measured. Moreover, there can be also cross-reactivity between the antibodies produced in an organism hence a diagnosis based on antibodies can also have a false positivity. Basic specifications of COVID-19 and SARS-CoV-2 as outcomes for diagnosis are summarized in Table 1 .

Simple immunoassays for a SARS-CoV-2 antigen can be an alternative for diagnosis based on antibodies. For instance, a microfluidic immunoassay for the detection of serum antibodies IgG and IgM specific to SARS-CoV-2 and immunodetection of antigen isolated by pharyngeal swabs was successfully developed and reported by Lin and co-workers (60). Another approach was proposed by Mavrikou and co-workers, who developed a membrane engineered cell cowered human chimeric anti spike - S1 antibody and interacting with S1 spike S protein from SARS-CoV-2 (61). The interaction resulted in a generation of a membrane potential, which was measured as an outputting signal. The assay exerted the limit of detection $1 \mathrm{fg} / \mathrm{ml}$ and semi-linear response between $10 \mathrm{fg} / \mathrm{ml}$ and $1 \mu \mathrm{g} / \mathrm{ml}$ during an assay lasting 3 minutes. Biosensor for the detection of SARS-CoV-2 S protein was also developed by Seo and co-workers (62). The biosensor was based on field-effect transistor coated with graphene sheets with an antibody against SARS-CoV-2 S protein. The assay was suitable for the detection of virus in nasopharyngeal swab and virus growing in cell cultures. The assay was able to detect at least $16 \mathrm{PFU} / \mathrm{ml}$ in cell cultures and 242 viral copies in nasopharyngeal swab, the limit of detection for pure $\mathrm{S}$ protein was equal to $1 \mathrm{fg} / \mathrm{ml}$. There are also developed tests working on Lateral Flow Immunochromatography Assay (LFIA) principle. The commercially available BIOCREDIT COVID-19 $\mathrm{Ag}$ test suitable for proving of SARS-CoV-2 in nasopharyngeal swab sample can be mentioned as a relevant analytical tool. In the study by Mak and co-workers, the BIOCREDIT COVID-19 Ag test was compared to qRT PCR (63). The researchers stated that qRT PCR was 100,000 times more sensitive to SARS-CoV-2 than the BIOCREDIT COVID-19 Ag test and the risk of false negativity was the main disadvantage of BIOCREDIT COVID-19 Ag test. On the other hand, BIOCREDIT COVID-19 Ag test could be used easily outside of laboratories and could be provided in a pointof-care. The LFIA assay cannot replace the tests like qRT PCR or RT LAMP, but it could be used as a simple test for screening of population for COVID-19 and finding of infected communities.

\section{Diagnostic based on antibodies}

Antibodies are an important and specific marker of infectious diseases. Concentration of immunoglobulins is quite high in the blood. The most common antibodies from the group of immunoglobulins (Ig) G, IgM and IgA reaches typically $7-16 \mathrm{mg} / \mathrm{ml}$ for $\mathrm{IgG}, 0.4-2.3 \mathrm{mg} / \mathrm{ml}$ for IgA or $0.4-2.3$ for IgM in serum, but the level can be significantly increased due to some pathological processes including infectious diseases (64-67). Amplification of an stimuli is the major advantage of diagnoses based on antibodies assay, it means that a relatively low amount of antigen causes a significantly higher production of antibodies and not the original antigen, but the propagated antibodies are detected. All the isotypes, IgG, IgM and IgA, are increased and applicable for COVID-19 diagnosis, which was for instance reported by the study on 21 Croatian patients, where serum samples were tested by standard Enzyme-Linked Immunosorbent Assay (ELISA) (68). The overall high level of antibodies in combination with the extensive change in antibodies concentrations make them an ideal biological marker. In the case of COVID-19, production of antibodies has not been researched enough to make a single conclusion. While humoral immunity is studied and certainly take place in the infected people (69), some studies proved that the immunity is quite naïve for SARS-CoV-2 and some people have a quite limited response. For instance, Bahar and co-workers revealed that only 17 patients from a group of 33 people suffering of COVID-19 had an adequate neutralizing antibodies level (70). Therefore, the results from diagnoses focused on antibodies measuring should be considered as suspicious until the whole issue is cleared. The production of antibodies in an organism is a time dependent process and the antibodies cannot be detected immediately after an infection transmission into host. In the work by Chughtai and co-workers, samples from COVID-19 patients were analysed for a specific antibodies production (71). They revealed seroconversion $68 \%$ at day 7 post-symptom onset. The percentage reached $88 \%$ for 14 days and $100 \%$ for 21 days after symptoms onset. For the reason, the conclusion about immune system naivety for COVID-19 should consider a time span of infection starting.

ELISA is the standard and probably the most common method for the measuring of antibodies level in blood, blood serum and blood plasma and the detection of antibodies against SARS-CoV-2 is currently used as well (72-76). LFIA in the form of test strips is another standardized and evolving method for anti-SARS-CoV-2 antibodies detection (77-79). Beside the methods common in clinical praxis, other immunoassays, immunosensors, and immunoblotting tests are applicable for the antibodies detection (80-82).

An ELISA test for COVID-19 diagnosis is typically focused on antibodies specific to surface proteins, the anti-S1 protein antibodies appears to be suitable for the diagnosis $(83,84)$. Beside the standard diagnosis of the COVID-19, ELISA is also a routine method for measuring the antibodies level in people that underwent vaccination or clinical trials in development of an anti-COVID-19 vaccine and efficacy of seroconversion due to vaccination is thus determined (85). Research and characterization of developed monoclonal antibodies can be done by ELISA as well (86). 
Tab. 2. Overview of samples and methods for COVID-19 instrumental diagnosis.

\begin{tabular}{lll}
\hline Marker & Methods & Samples \\
\hline \multirow{2}{*}{ viral RNA including RNA in intact virions } & $\begin{array}{l}\text { Polymerase Chain Reaction (PCR), Loop- } \\
\text { mediated isothermal Amplification (LAMP) }\end{array}$ & $\begin{array}{l}\text { saliva, throat swab samples, nasopharyngeal } \\
\text { swab samples blood, serum, plasma }\end{array}$ \\
\hline \multirow{2}{*}{$\begin{array}{l}\text { surface S and N proteins including proteins on } \\
\text { intact virions }\end{array}$} & $\begin{array}{l}\text { Lateral Flow Immunochromatography Assay } \\
\text { (LFIA), Enzyme-Linked Immunosorbent Assay }\end{array}$ & $\begin{array}{l}\text { saliva, throat swab samples, nasopharyngeal } \\
\text { swab samples blood, serum, plasma }\end{array}$ \\
\hline (ELISA), biosensors and ChemiLuminescence & blood, serum, plasma \\
\hline
\end{tabular}

ELISA is convenient for measuring of trace level of antibodies so it can serve for the purpose of epidemiologic studies and it can retroactively identify patients with a mild manifestation of the disease that were not revealed during the disease (87). Kovac and co-workers. tested commercial tests based on chemiluminescence immunoassays principle (CLIA test; Roche, Rotkreuz, Switzerland) and ELISA (IgG and IgA ELISA test; Euroimmun, Lubeck, Germany) for haemolyzed blood samples and reported them as the optimal for antibodies testing in the laboratory conditions (88). They placed the ELISA and ECLIA test above LFIA. In another paper, CLIA test (Abbott SARS-CoV-2 CLIA IgG; Abbott Laboratories, Illinois, USA), ELISA tests (Euroimmun Anti-SARS-CoV-2 ELISA IgG/IgA; Euroimmun) and LFIA tests (LFIA NG-Test IgGIgM COVID-19; NG Biotech, Guipry, France) were tested on 293 specimens and the researchers compared them mutually (89). They reported $100 \%$ sensitivity for all methods, when samples from patients were taken 14 days after symptoms onset. Overall specificity for IgG was above $98 \%$ for CLIA and LFIA and $95.8 \%$ for ELISA. The authors concluded their study by a statement that all the methods are reliable and accurate enough to be performed in clinical laboratories. The diagnoses based on antibodies can be further supported or confirmed by the analysis of cytokines and evaluation of cellular immunity by e.g. flow cytometry (90-96). Basic specifications of COVID-19 and SARS-CoV-2 as outcomes for diagnosis are summarized in the Table 1. Overview samples and methods for COVID-19 diagnosis described in the text above are written in the Table 2.

\section{Conclusions}

Instrumental diagnosis of COVID-19 can be made by a wide number of techniques allowing a reliable identification of pathogen or markers and the disease can be plausibly confirmed or neglected by these techniques. Combination of genetic test like PCR and revealing of specific antibodies is adequate for most of the scenarios. On the other hand, there are other methods and some of them are applicable in point-of-care diagnosis though they are less sensitive than the standard laboratory test. Development of new methods on COVID-19 instrumental diagnosis can be expected because of extensive and intensive research. Significant changes in the standard laboratory methods for COVID-19 instrumental diagnosis are not expected, but development of portable devices, kits etc. is probable.

\section{References}

1. Moore JX, Langston ME, George V, Coughlin SS. Epidemiology of the 2020 pandemic of covid-19 in the state of georgia: Inadequate critical care resources and impact after 7 weeks of community spread. J Am Coll Emerg Physicians Open 2020; 26 (10): 12127.

2. Zhang N, Yao H, Zhang D et al. Epidemiologic and clinical characteristics of 42 deaths caused by sars-cov- 2 infection in wuhan, china: A retrospective study. Biosaf Health 2020; DOI: 10.1016/j.bsheal.2020.07.007.

3. Kaur N, Gupta I, Singh $\mathbf{H}$ et al. Epidemiological and clinical characteristics of 6635 covid-19 patients: A pooled analysis. SN Compr Clin Med 2020; 9: 1-5.

4. Prezioso C, Pietropaolo V. Covid-19: Update of the italian situation. J Neurovirol 2020; 8 (10): 020-00900.

5. Liu J, Wang L, Zhang Q, Yau ST. The dynamical model for covid-19 with asymptotic analysis and numerical implementations. Appl Math Model 2020; 8 (10): 057

6. Larson C, Oronsky B, Goyal S et al. Covid-19 and cancer: A guide with suggested covid-19 rule-out criteria to support clinical decision-making. Biochim Biophys Acta Rev Cancer 2020; 19 (188412): 188412.

7. Nikolai LA, Meyer CG, Kremsner PG, Velavan TP. Asymptomatic sars coronavirus 2 infection: Invisible yet invincible. Int J Infect Dis 2020; 3 (20): 30706-30702.

8. Furukawa NW, Brooks JT, Sobel J. Evidence supporting transmission of severe acute respiratory syndrome coronavirus 2 while presymptomatic or asymptomatic. Emerg Infect Dis 2020; 26 (7): e201595.

9. Lai CC, Liu YH, Wang CY et al. Asymptomatic carrier state, acute respiratory disease, and pneumonia due to severe acute respiratory syndrome coronavirus 2 (sars-cov-2): Facts and myths. J Microbiol Immunol Infect 2020; 53 (3): 404-412.

10. Kuttiatt VS, Abraham PR, Menon RP, Vaidya PC, Rahi M. Coronavirus disease 2019 in children: Clinical \& epidemiological implications. Indian J Med Res 2020; 17 (10).

11. Agbelele P, Vanmaris F, Sanguina M, Zerkly B, Djebara AE, Girard $\mathbf{P}$. Use of chest ct-scan images to differentiate between sars-cov-2 infection and fat embolism: A clinical case. Radiol Case Rep 2020; DOI: 10.1016/j.radcr.2020.07.071.

12. Jedrusik P, Gaciong Z, Sklinda K, Sierpinski R, Walecki J, Gujski M. Diagnostic role of chest computed tomography in coronavirus disease 2019. Pol Intern Med 2020; 130 (6): 520-528.

13. Rawashdeh MA, Saade C. Radiation dose reduction considerations and imaging patterns of ground glass opacities in coronavirus: Risk of over exposure in computed tomography. Radiol Med 2020; 8 (10): 020-01271.

14. Caruso D, Polidori T, Guido G et al. Typical and atypical covid-19 computed tomography findings. World J Clin Cases 2020; 8 (15): 3177-3187. 
15. Khan A, Tahir Khan M, Saleem S et al. Structural insights into the mechanism of rna recognition by the n-terminal rna-binding domain of the sars-cov-2 nucleocapsid phosphoprotein. Comput Struct Biotechnol J 2020; 18: 2174-2184.

16. Kubina R, Dziedzic A. Molecular and serological tests for covid-19 a comparative review of sars-cov-2 coronavirus laboratory and point-ofcare diagnostics. Diagnostics 2020; 10 (6): 434.

17. D’Cruz RJ, Currier AW, Sampson VB. Laboratory testing methods for novel severe acute respiratory syndrome-coronavirus-2 (sars-cov-2). Front Cell Dev Biol 2020; 8: 468.

18. Naqvi AAT, Fatima K, Mohammad T et al. Insights into sars-cov-2 genome, structure, evolution, pathogenesis and therapies: Structural genomics approach. Biochim Biophys Acta Mol Basis Dis 2020; 1 (10): 13.

19. Forouzesh M, Rahimi A, Valizadeh R, Dadashzadeh N, Mirzazadeh A. Clinical display, diagnostics and genetic implication of novel coronavirus (covid-19) epidemic. Eur Rev Med Pharmacol Sci 2020; 24 (8): 4607-4615.

20. Wakida H, Kawata K, Yamaji Y et al. Stability of rna sequences derived from the coronavirus genome in human cells. Biochem Biophys Res Commun 2020; 527 (4): 993-999.

21. Sullivan PS, Sailey C, Guest JL et al. Detection of sars-cov-2 rna and antibodies in diverse samples: Protocol to validate the sufficiency of provider-observed, home-collected blood, saliva, and oropharyngeal samples. JMIR Public Health Surveill 2020; 6 (2): 19054.

22. Mesoraca A, Margiotti K, Viola A, Cima A, Sparacino D, Giorlandino C. Evaluation of sars-cov-2 viral rna in fecal samples. Virol J 2020; 17 (1): 86.

23. Freire-Paspuel B, Vega-Mariño P, Velez A et al. Cotton-tipped plastic swabs for sars-cov-2 rt-qper diagnosis to prevent supply shortages. Front Cell Infect Microbiol 2020; 10 (356).

24. Federman DG, Gupta S, Stack G et al. Sars-cov-2 detection in setting of viral swabs scarcity: Are mrsa swabs and viral swabs equivalent? PLoS One 2020; 15 (8).

25. Hirotsu Y, Maejima M, Shibusawa $M$ et al. Comparison of automated sars-cov-2 antigen test for covid-19 infection with quantitative rtpcr using 313 nasopharyngeal swabs including from 7 serially followed patients. Int J Infect Dis 2020; 12 (20): S1201-9712(1220)30658-30655.

26. Lin C, Xiang J, Yan M, Li H, Huang S, Shen C. Comparison of throat swabs and sputum specimens for viral nucleic acid detection in 52 cases of novel coronavirus (sars-cov-2)-infected pneumonia (covid-19). Clin Chem Lab Med 2020; 58 (7): 1089-1094.

27. Igloi Z, Leven M, Abou-Nouar ZAK et al. Comparison of commercial realtime reverse transcription pcr assays for the detection of sars-cov-2. J Clin Virol 2020; 129: 104510.

28. Perchetti GA, Nalla AK, Huang ML, Jerome KR, Greninger AL. Multiplexing primer/probe sets for detection of sars-cov-2 by qrt-pcr. J Clin Virol 2020; 129.

29. Dorlass EG, Monteiro CO, Viana AO et al. Lower cost alternatives for molecular diagnosis of covid-19: Conventional rt-pcr and sybr greenbased rt-qpcr. Braz J Microbiol 2020; DOI: 10.1007/s42770-020-00347-5.

30. Adams NM, Leelawong M, Benton A, Quinn C, Haselton FR, Schmitz JE. Covid-19 diagnostics for resource-limited settings: Evaluation of "unextracted" qrt-cr. J Med Virol 2020; DOI: 10.1002/jmv.26328.

31. Cipitelli MDC, Valentin E, da Cruz NVG et al. Sars-cov-2 diagnostic diary: From rumors to the first case. Early reports of molecular tests from the military research and diagnostic institute of rio de janeiro. Mem Inst Oswaldo Cruz 2020; 115 (10): e200200.

32. Bulterys PL, Garamani N, Stevens B et al. Comparison of a laboratory-developed test targeting the envelope gene with three nucleic acid amplification tests for detection of sars-cov-2. J Clin Virol 2020; 129: 104427.

33. Liu Y, Wang Y, Wang $X$ et al. Development of two taqman real-time reverse transcription-pcr assays for the detection of severe acute respiratory syndrome coronavirus-2. Biosaf Health 2020; 23 (10): 009.

34. Baek YH, Um J, Antigua KJC et al. Development of a reverse transcription-loop-mediated isothermal amplification as a rapid early-detection method for novel sars-cov-2. Emerg Microbes Infect 2020; 9 (1): 998-1007.

35. Jiang MH, Pan WH, Arasthfer A et al. Development and validation of a rapid, single-step reverse transcriptase loop-mediated isothermal amplification (rt-lamp) system potentially to be used for reliable and high-throughput screening of covid-19. Front Cell Infect Microbiol 2020; 10: 331.

36. Lau YL, Ismail I, Mustapa NI et al. Real-time reverse transcription loop-mediated isothermal amplification for rapid detection of sars-cov-2. PeerJ 2020; 8: e9278.

37. Lamb LE, Bartolone SN, Ward E, Chancellor MB. Rapid detection of novel coronavirus/severe acute respiratory syndrome coronavirus 2 (sars-cov-2) by reverse transcription-loop-mediated isothermal amplification. PLoS One 2020; 15 (6): e0234682.

38. James AS, Alwneh JI. Covid-19 infection diagnosis: Potential impact of isothermal amplification technology to reduce community transmission of sars-cov-2. Diagnostics 2020; 10 (6): 399.

39. Park GS, Ku K, Baek SH et al. Development of reverse transcription loop-mediated isothermal amplification assays targeting severe acute respiratory syndrome coronavirus 2 (sars-cov-2). J Mol Diagn 2020; 22 (6): 729-735.

40. Yan C, Cui J, Huang L et al. Rapid and visual detection of 2019 novel coronavirus (sars-cov-2) by a reverse transcription loop-mediated isothermal amplification assay. Clin Microbiol Infect 2020; 26 (6): 773-779.

41. Huang WE, Lim B, Hsu CC et al. Rt-lamp for rapid diagnosis of coronavirus sars-cov-2. Microb Biotechnol 2020; 13 (4): 950-961.

42. Lu RF, Wu XM, Wan ZZ, Li YX, Jin X, Zhang CY. A novel reverse transcription loop-mediated isothermal amplification method for rapid detection of sars-cov-2. Int J Mol Sci 2020; 21 (8): 2826.

43. Cui ZF, Chang $\mathbf{H}$, Wang $\mathbf{H}$ et al. Development of a rapid test kit for sars-cov-2: An example of product design. Bio-Des Manuf 2020; 3 (2): $83-86$.

44. Thi VLD, Herbst K, Boerner $K$ et al. A colorimetric rt-lamp assay and lamp-sequencing for detecting sars-cov-2 rna in clinical samples. Sci Transl Med 2020; 12 (556): eabc7075.

45. Chow FWN, Chan TTY, Tam AR et al. A rapid, simple, inexpensive, and mobile colorimetric assay covid-19-lamp for mass on-site screening of covid-19. Int J Mol Sci 2020; 21 (15): 5380.

46. Muhammed Y. Molecular targets for covid-19 drug development: Enlightening nigerians about the pandemic and future treatment. Biosaf Health 2020; 9 (10): 002.

47. Accinelli RA, Zhang Xu CM, Ju Wang JD et al. Covid-19: La pandemia por el nuevo virus sars-cov-2. Rev Peru Med Exp Salud Publica 2020; 37 (2): 302-311.

48. Kumari P, Singh A, Ngasainao MR et al. Potential diagnostics and therapeutic approaches in covid-19. Clin Chim Acta 2020; 510: 488-497. 
49. Ming Y, Qiang L. Involvement of spike protein, furin, and ace 2 in sars-cov-2-related cardiovascular complications. SN Compr Clin Med 2020; 11: $1-6$.

50. Fierabracci A, Arena A, Rossi P. Covid-19: A review on diagnosis, treatment, and prophylaxis. Int J Mol Sci 2020; 21 (14): 5145.

51. Bhole RP, Sarode VI, Bonde CG. Understanding and implementing alternative solutions to address the covid-19 pandemic in the sense of public health emergencies. Eur Rev Med Pharmacol Sci 2020; 24 (13): 7485-7493.

52. Chen Y, Qiu F. Spike protein in the detection and treatment of novel coronavirus. Sheng Wu Yi Xue Gong Cheng Xue Za Zhi 2020; 37 (2): 246-250.

53. Parker R, Partridge T, Wormald C et al. Mapping the sars-cov-2 spike glycoprotein-derived peptidome presented by hla class ii on dendritic cells. bioRxiv 2020; DOI: 10.1101/2020.08.19.255901.

54. Tohidinia M, Sefid F. Identification $b$ and $t$-cell epitopes and functional exposed amino acids of s protein as a potential vaccine candidate against sars-cov-2/covid-19. Microb Pathog 2020; 148: 104459.

55. Nuovo G, Tili E, Suster D, Matys E, Hupp L, Magro C. Strong homology between sars-cov-2 envelope protein and a mycobacterium sp. Antigen allows rapid diagnosis of mycobacterial infections and may provide specific anti-sars-cov-2 immunity via the bcg vaccine. Ann Diagn Pathol 2020; 48 (151600): 151600.

56. Jaroszewski L, Iyer M, Alisoltani A, Sedova M, Godzik A. The interplay of sars-cov-2 evolution and constraints imposed by the structure and functionality of its proteins. bioRxiv 2020; DOI: $10.1101 / 2020.08 .10 .244756$

57. Facchetti F, Bugatti M, Drera E et al. Sars-cov2 vertical transmission with adverse effects on the newborn revealed through integrated immunohistochemical, electron microscopy and molecular analyses of placenta. EBioMedicine 2020; 59: 102951.

58. Awasthi M, Gulati S, Sarkar DP et al. The sialoside-binding pocket of sars-cov-2 spike glycoprotein structurally resembles mers-cov. Viruses 2020; 12 (9): E909.

59. Lustig Y, Keler S, Kolodny R et al. Potential antigenic cross-reactivity between sars-cov-2 and dengue viruses. Clin Infect Dis 2020; 14 (10): 1207.

60. Lin QY, Wen DH, Wu J et al. Microfluidic immunoassays for sensitive and simultaneous detection of igg/igm/antigen of sars-cov-2 within 15 min. Anal Chem 2020; 92 (14): 9454-9458.

61. Mavrikou S, Moschopoulou G, Tsekouras V, Kintzios S. Development of a portable, ultra-rapid and ultra-sensitive cell-based biosensor for the direct detection of the sars-cov-2 s1 spike protein antigen. Sensors 2020; 20 (11): 3121.

62. Seo G, Lee G, Kim MJ et al. Rapid detection of covid-19 causative virus (sars-cov-2) in human nasopharyngeal swab specimens using fieldeffect transistor-based biosensor. ACS Nano 2020; 14 (4): 5135-5142.

63. Mak GCK, Cheng PKC, Lau SSY et al. Evaluation of rapid antigen test for detection of sars-cov-2 virus. J Clin Virol 2020; 129: 104500.

64. Banavali A, Neculiseanu E, Draksharam PL et al. Clinical characteristics of hyposecretory multiple myeloma (monoclonal immunoglobulin $<3 \mathrm{~g} / \mathrm{dl}$ ) in afro-caribbean patients at a single urban institution. Blood $2016 ; 128(22)$

65. Thanthitaweewat V, Chantranuwatana $P$, Chirakalwasan N. Immunoglobulin g4-related disease: A rare steroidresponsive disease. Respirol Case Rep 2017; 5 (3).
66. Pohanka M. Evaluation of immunoglobulin production during tularaemia infection in balb/c mouse model. Acta Vet Brno 2007; 76: 579-584.

67. Pohanka M. Piezoelectric immunosensor for the determination of immunoglobulin g. Int J Electrochem Sc 2018; 13: 8784-8791.

68. Rode O, Kurolt IC, Puljiz I et al. Antibody response and the clinical presentation of patients with covid-19 in croatia: The importance of a two-step testing approach. Eur J Clin Microbiol Infect Dis 2020; 4 (10): 020-04019.

69. Baumgarth N, Nikolich-Žugich J, Lee FE, Bhattacharya D. Antibody responses to sars-cov-2: Let's stick to known knowns. J Immunol 2020; 4 (10): 2000839.

70. Bahar B, Jacquot C, Mo YD, DeBiasi RL, Campos J, Delaney M. Kinetics of viral clearance and antibody production across age groups in sars-cov-2 infected children. J Pediatr Gastroenterol Nutr 2020; 2 (20): 31114-31118.

71. Chughtai OR, Batool H, Khan MD, Ashraf S. Seroconversion in newly diagnosed cases of coronavirus disease. J Coll Physicians Surg Pak 2020; 30 (8): 801-804.

72. Gozalbo-Rovira R, Gimenez E, Latorre V et al. Sars-cov-2 antibodies, serum inflammatory biomarkers and clinical severity of hospitalized covid-19 patients. J Clin Virol 2020; 131: 104611.

73. Focosi D, Anderson AO, Tang JW, Tuccori M. Convalescent plasma therapy for covid-19: State of the art. Clin Microbiol Rev 2020; 33 (4): e00072-00020.

74. Ejazi SA, Ghosh S, Ali N. Antibody detection assays for covid-19 diagnosis: An early overview. Immunol Cell Biol 2020; 30 (10): 12397.

75. Rastawicki W, Rokosz-Chudziak N. Characteristics and assessment of the usefulness of serological tests in the diagnostic of infections caused by coronavirus sars-cov- 2 on the basis of available manufacturer's data and literature review. Przegl Epidemiol 2020; 74 (1): 49-68.

76. Herrmann BL. The prevalence rate of anti-sars-cov-2-igg is $1.2 \%$ screening in asymptomatic outpatients in germany (northrhine-westfalia). MMW Fortschr Med 2020; 162 (14): 44-46.

77. Deeks JJ, Dinnes J, Takwoingi Y et al. Antibody tests for identification of current and past infection with sars-cov-2. Cochrane Database Syst Rev 2020; 6 (6): CD013652.

78. Huang C, Wen T, Shi F J, Zeng XY, Jiao Y J. Rapid detection of igm antibodies against the sars-cov-2 virus via colloidal gold nanoparticle-based lateral-flow assay. ACS Omega 2020; 5 (21): 12550-12556.

79. Cui F, Zhou HS. Diagnostic methods and potential portable biosensors for coronavirus disease 2019. Biosens Bioelectron 2020; 165: 112349.

80. Li T, Zheng Q, Yu H et al. Sars-cov-2 spike produced in insect cells elicits high neutralization titers in non-human primates. Emerg Microbes Infect 2020; 8: 1-44.

81. Maremanda KP, Sundar IK, Li D, Rahman I. Age-dependent assessment of genes involved in cellular senescence, telomere and mitochondrial pathways in human lung tissue of smokers, copd and ipf: Associations with sars-cov-2 covid-19 ace2-tmprss2-furin-dpp4 axis. Res Sq 2020; rs.3.rs-35347.

82. Tymm C, Zhou J, Tadimety A, Burklund A, Zhang JXJ. Scalable covid-19 detection enabled by lab-on-chip biosensors. Cell Mol Bioeng 2020; 10: $1-17$.

83. Behrens GMN, Cossmann A, Stankov MV et al. Strategic anti-sarscov-2 serology testing in a low prevalence setting: The covid-19 contact 
(coco) study in healthcare professionals. Infect Dis Ther 2020; 4 (10): 020-00334.

84. Chaudhuri S, Thiruvengadam R, Chattopadhyay S et al. Comparative evaluation of sars-cov-2 igg assays in india. J Clin Virol 2020; 131 (104609): 104609.

85. Keech C, Albert G, Cho I et al. Phase 1-2 trial of a sars-cov-2 recombinant spike protein nanoparticle vaccine. N Engl J Med 2020; 2 (10).

86. Zheng Z, Monteil VM, Maurer-Stroh S et al. Monoclonal antibodies for the s2 subunit of spike of sars-cov-1 cross-react with the newly-emerged sars-cov-2. Euro Surveill 2020; 25 (28): 1560-7917.

87. Younas A, Waheed S, Khawaja S, Imam M, Borhany M, Shamsi T. Seroprevalence of sars-cov-2 antibodies among healthy blood donors in karachi, pakistan. Transfus Apher Sci 2020; 24 (102923): 102923.

88. Kovac M, Risch L, Thiel S et al. Edta-anticoagulated whole blood for sars-cov-2 antibody testing by electrochemiluminescence immunoassay (eclia) and enzyme-linked immunosorbent assay (elisa). Diagnostics 2020; 10 (8): E593.

89. Nicol T, Lefeuvre C, Serri $O$ et al. Assessment of sars-cov-2 serological tests for the diagnosis of covid-19 through the evaluation of three immunoassays: Two automated immunoassays (euroimmun and abbott) and one rapid lateral flow immunoassay (ng biotech). J Clin Virol 2020; 129 (104511): 104511
90. Chattopadhyay PK, Filby A, Jellison ER et al. A cytometrist's guide to coordinating and performing effective covid-19 research. Cytometry A 2020; 16 (10): 24210

91. Zhang S, Liu Y, Wang $X$ et al. Sars-cov-2 binds platelet ace2 to enhance thrombosis in covid-19. J Hematol Oncol 2020; 13 (1): 120.

92. Gong F, Dai $\mathbf{Y}$, Zheng $\mathbf{T}$ et al. Peripheral $\mathrm{cd} 4+\mathrm{t}$ cell subsets and antibody response in covid-19 convalescent individuals. J Clin Invest 2020; 25 (141054).

93. Han M, Xu M, Zhang $\mathbf{Y}$ et al. Assessing sars-cov-2 rna levels and lymphocyte/t cell counts in covid-19 patients revealed initial immune status as a major determinant of disease severity. Med Microbiol Immunol 2020; 28 (10): 020-00693.

94. Peruzzi B, Bencini S, Capone M et al. Quantitative and qualitative alterations of circulating myeloid cells and plasmacytoid dc in sars-cov-2 infection. Immunology 2020; 1 (10): 13254.

95. Peng Y, Mentzer AJ, Liu G et al. Broad and strong memory cd4(+) and cd8(+) t cells induced by sars-cov-2 in uk convalescent individuals following covid-19. Nat Immunol 2020; 4 (10): 020-0782.

96. Gniffke EP, Harrington WE, Dambrauskas $\mathbf{N}$ et al. Plasma from recovered covid-19 subjects inhibits spike protein binding to ace 2 in a microsphere-based inhibition assay. J Infect Dis 2020; 15 (10): jiaa508.

Received September 11, 2020 Accepted December 2, 2020. 